\title{
EXPERIMENTAL EVIDENCE FOR PLANAR PSEUDOPERICYCLIC TRANSITION STATES IN THERMAL CHELETROPIC DECARBONYLATIONS
}

\author{
Han-Xun Wei, Chun Zhou, Sihyun Ham, Jonathan M. White* and David M. Birney* \\ Department of Chemistry and Biochemistry \\ Texas Tech University \\ Lubbock, TX 79401-1061, USA \\ School of Chemistry \\ University of Melbourne \\ Parkville, Vic 3010, AUSTRALIA
}

\section{SUPPORTING INFORMATION}

Table of Contents

Page

$\begin{array}{ll}\text { General experimental procedures } & \text { S2 }\end{array}$

Syntheses of compounds $\mathbf{3}-\mathbf{9}$; spectral data for new compounds $\mathbf{4 , 7 , 8 , 9} \quad$ S2

Results and discussion of Cambridge Structural Database searches $\quad$ S5

Selected geometric parameters of $\mathbf{1}$ and $\mathbf{2}$ at the MP2/6-31G* level S10

${ }^{1} \mathrm{H}$ and ${ }^{13} \mathrm{C}$ NMR of $\mathbf{4 , 7 , 8 , 9} \quad \mathrm{S} 11$

$\begin{array}{ll}\text { X-ray crystallographic data for compound } 4 & \text { S18 }\end{array}$

$\begin{array}{ll}\text { References } & \text { S24 }\end{array}$ 


\section{General experimental procedures.}

Reaction solvents were freshly distilled. Other reactants and chromatography solvents were used as supplied. Flash chromatography was done using 230-400 mesh 60 Å flash grade silica gel. NMR spectra were obtained on a Bruker $300 \mathrm{MHz}$ or Varian INOVA $500 \mathrm{MHz}$ Fourier transform spectrometer at Texas Tech University. X-ray crystal structures were determined at $130 \mathrm{~K}$ at the University of Melbourne, Australia, unless otherwise noted.

4-Benzoyl-1,5-diphenyl-2,3-dihydropyrrole-2,3-dione (3). Pyrroledione 3 was prepared by the reaction of the imine of dibenzoylmethane and aniline ${ }^{1}$ with oxalyl chloride as described as literature. ${ }^{2}$ It was recrystallized from a mixture of hexane and chloroform (mp $\left.102-104^{\circ} \mathrm{C}\right)$ for X-ray crystallography.

\section{4-Benzoyl-1,5-dihydro-3,5-dimethoxy-1,5-diphenyl-2H-pyrrol-2-one (7). A modified} procedure of Kappe et al. ${ }^{3}$ was adopted here. Dione 3 (353 mg, $1.0 \mathrm{mmol}$ ) was stirred with absolute $\mathrm{MeOH}(4 \mathrm{~mL})$ for $2 \mathrm{~h}$. Then $\mathrm{TMSCl}(1.0 \mathrm{~mL})$ was added to this solution. ${ }^{3}$ The mixture was stirred at rt for $10 \mathrm{~h}$. The excess of $\mathrm{MeOH}$ and $\mathrm{TMSCl}$ were evaporated and the residue was purified by column chromatography (hexane : ethyl acetate $=100 / 20(\mathrm{v} / \mathrm{v})$ ) to give 7 as a pale yellow solid (302 mg, 75.4\% yield). Compound 7 was recrystallized from absolute ethanol, which was submitted for X-ray analysis. ${ }^{1} \mathrm{H}$ NMR (500 MHz, $\mathrm{CDCl}_{3}$ ) $\delta 3.55$ (s, 3H), 3.79 (s, 3H), 7.05 7.13 (m, 4H), 7.22 7.29 (m, 4H), 7.36 7.38 (m, 2H), 7.42 7.45 (m, 1H), 7.54 7.56 (m, 2H), 7.62 7.64 (m, 2H); $\left.{ }^{13} \mathrm{C} \mathrm{NMR} \mathrm{(125} \mathrm{MHz,} \mathrm{CDCl}_{3}\right) \delta$ 50.45, 59.81, 95.95, 121.37, 122.25, $125.46,125.99,128.25,128.36,128.37,128.65,128.93,133.45,135.75,137.00,137.66,148.15$, $164.01,190.83$.<smiles>O=C1C(=O)N(c2ccccc2)C(c2ccccc2)=C1C(=O)c1ccccc1</smiles><smiles>COC1=C(C(=O)c2ccccc2)C(OC)(c2ccccc2)N(c2ccccc2)C1=O</smiles>

5-(4-Nitrophenyl)-1-propyl-2,3-dihydropyrrole-2,3-dione (4). In a $100 \mathrm{~mL}$ round bottomed flask was placed $1.55 \mathrm{~g}(9.39 \mathrm{mmol})$ of p-nitroacetophenone, $1.11 \mathrm{~g}(18.8 \mathrm{mmol})$ of propylamine 
and $20 \mathrm{~mL}$ of dichloromethane. To this was added $2 \mathrm{~g}$ of $4 \AA$ molecular sieves and the reaction mixture was refluxed with stirring for 11 hours. The reaction mixture was filtered to remove the sieves and then the solvent and excess propylamine were removed under vacuum. The crude yield was $1.81 \mathrm{~g}$ (94\% yield, 92\% pure by NMR). This was used directly in the next step.<smiles>CCCN=C(C)P(=O)(O[Na])O[Na]</smiles>

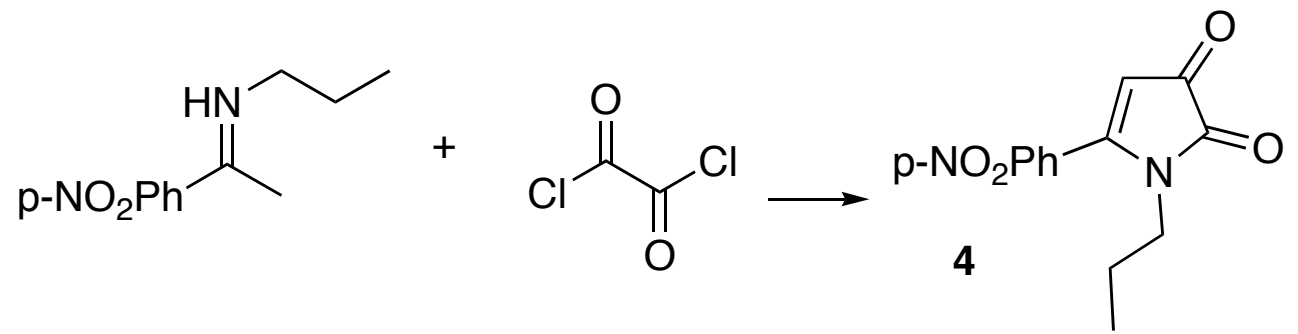

Oxalyl chloride $(0.85 \mathrm{~mL}, 9.8 \mathrm{mmol})$ was dissolved in $18 \mathrm{~mL}$ distilled $\mathrm{CH}_{2} \mathrm{Cl}_{2}$ in a $100 \mathrm{~mL}$ threenecked flask under nitrogen. The crude imine $(1.81 \mathrm{~g}, 8.8 \mathrm{mmol})$ was dissolved in $10 \mathrm{~mL}$ of distilled $\mathrm{CH}_{2} \mathrm{Cl}_{2}$ and transferred to an addition funnel. This was added to the oxalyl chloride over $1 \mathrm{~h}$. Then triethylamine $(2.5 \mathrm{~mL}, 19 \mathrm{mmol})$ in $10 \mathrm{~mL} \mathrm{CH}_{2} \mathrm{Cl}_{2}$ was added over $30 \mathrm{~min}$. The color changed from pale yellow to dark yellow. The reaction mixture was diluted with ether, extracted with aqueous $\mathrm{NaHCO}_{3}$, brine, brine, acidified with $\mathrm{HCl}$, neutralized with aqueous $\mathrm{NaHCO}_{3}$, and brine. It was dried with $\mathrm{MgSO}_{4}$, and the solvents were evaporated. The crude yield of the pyrroledione was $1.92 \mathrm{~g}(83 \%)$. It was purified by flash column chromatography on silica gel, with 40/60 ether/hexane and then 50/50 ether/hexane as eluent. UV $\lambda_{\max } 277 \mathrm{~nm}, 245 \mathrm{~nm} .{ }^{1} \mathrm{H}$ NMR (300 MHz, CDCl $)_{3} \delta 0.77$ (t, $J=7.4 \mathrm{~Hz}, 3 \mathrm{H}$ ), 1.41 (sextet, $J=7.5 \mathrm{~Hz}, 2 \mathrm{H}$ ), 3.54 (pseudo $\mathrm{t}, J=7.5,2 \mathrm{H}), 5.53(\mathrm{~s}, 1 \mathrm{H}), 7.71(\mathrm{~d}, J=4.8,2 \mathrm{H}), 8.41(\mathrm{~d}, J=4.8,2 \mathrm{H}) \cdot{ }^{13} \mathrm{C} \mathrm{NMR}(75 \mathrm{MHz}$, $\left.\mathrm{CDCl}_{3}\right) \delta$ 11.00, 22.27, 43.08, 101.91, 124.50, 128.54, 135.39, 149.64, 158.92, 170.27, 182.98 . The sample for X-ray crystallography was recrystallized from ether. X-ray diffraction data was collected at rt on a Bruker Model P4 X-ray Diffractometer by Dr. Bruce R. Whittlesey at Texas Tech University. Note that the bond lengths in Table 2 have uncertainties of $\pm 0.004 \AA$ or less. 
Isatin (5). Commercially available isatin was recrystallized from ether for low temperature Xray crystallography. ${ }^{4}$<smiles>O=C1Nc2ccccc2C1=O</smiles>

5

1-Benzylpyrrolidine-2, 3-dione (6). Compound 6 was prepared following the procedure of Baldwin et al. ${ }^{5}$ and was recrystallized from $\mathrm{MeOH}$. Upon standing in the presence of moist air, crystals of $\mathbf{6}$ directly formed crystals of $\mathbf{8}$. This occurred during shipment of the crystals from Lubbock to Melbourne. The isomerization was revealed by X-ray crystallography. After the structure determination, the ${ }^{1} \mathrm{H}$ NMR of 8 was obtained. ${ }^{1} \mathrm{H}$ NMR $\left(500 \mathrm{MHz}, \mathrm{CDCl}_{3}\right) \delta 2.17$ (s, 2H), 3.73 (s, 2H), $4.02(\mathrm{~s}, 2 \mathrm{H}), 4.66(\mathrm{~s}, 2 \mathrm{H}), 6.45$ (s, 1H), 7.25-7.34 (m, 10H), $12.82(\mathrm{~s}, 1 \mathrm{H})$.<smiles>O=C1CCN(Cc2ccccc2)C1=O</smiles><smiles>O=C1C(C2=C(O)C(=O)N(Cc3ccccc3)C2)=CCN1Cc1ccccc1</smiles>

4,5-Diphenyl-2,3-dihydrofuran-2,3-dione (9). Furandione 9 was synthesized from 1trimethylsilyoxy-1,2-diphenylethylene ${ }^{6}$ and oxalyl chloride following the procedure as describe to prepare other furandiones. ${ }^{7}$ Compound 9 was identified by NMR and recrystallized from a mixture of hexane and chloroform for X-ray crystallography (mp $136-137^{\circ} \mathrm{C}$, red-orange obelisks). UV $1_{\max } 277,425 \mathrm{~nm} .{ }^{1} \mathrm{H}$ NMR (500 MHz, $\left.\mathrm{CDCl}_{3}\right) \delta 7.33 \sim 7.37$ (m, 2H), 7.40 7.48 (m, 5H), 7.57 7.61 (m, 1H), 7.76 7.79 (m, 2H); $\left.{ }^{13} \mathrm{C} \mathrm{NMR} \mathrm{(125} \mathrm{MHz,} \mathrm{CDCl}_{3}\right) \delta 117.51,126.73$, $127.37,129.00,129.13,129.16,129.19,129.20,134.30,154.36,172.79,179.08$. 
Results and discussion of Cambridge Structural Database searches. ${ }^{8}$

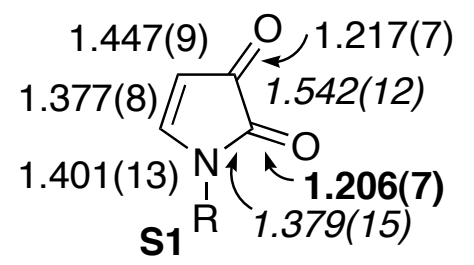

131.8(14)
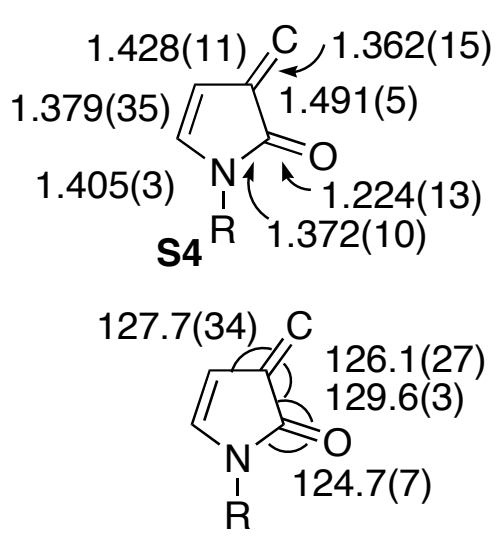
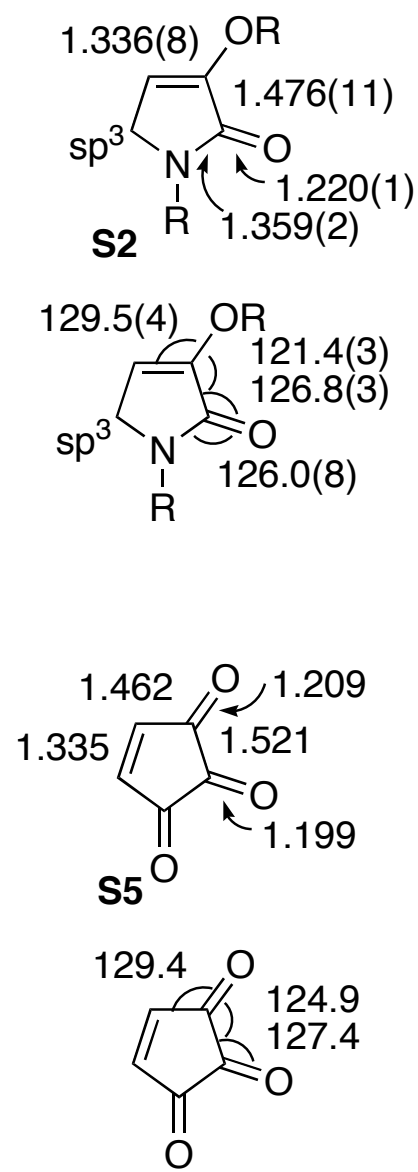
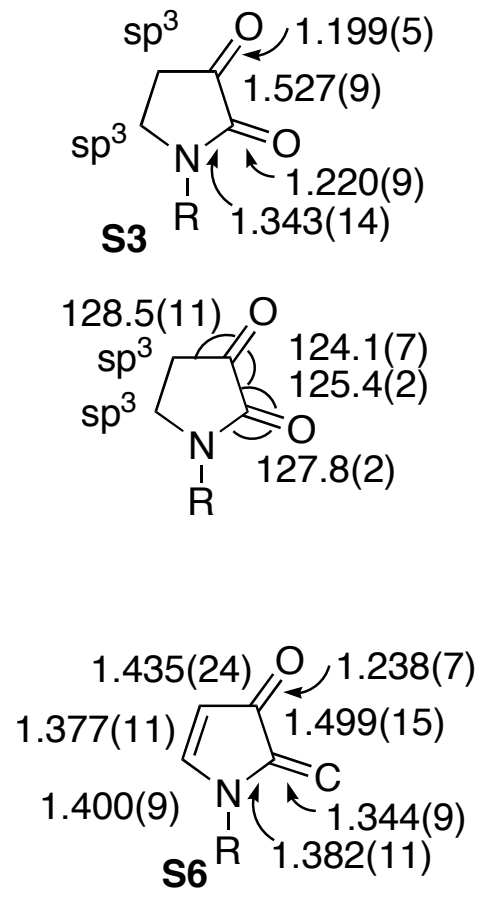

130.5(8)

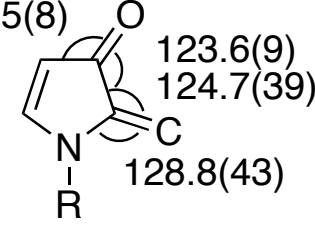

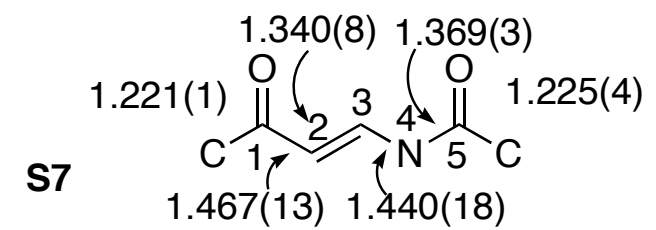

Figure S1. Average distances and angles in structures related to compounds $\mathbf{3}-\mathbf{8}$, based on searches of the Cambridge Structural Database. Distances in Ångstroms, angles in degrees, standard deviations in parentheses (least significant figures). Carbons with $\mathrm{sp}^{3}$ hybridization are so marked. These structures have R factors $<5 \%$. Atom numbering is as in S1. In S1, the structure/reactivity principle predicts distances in bold to be shorter, in italics to be longer than model systems. Angles in green are predicted to be more open. Values in red do not follow the predicted trends.

Structure $\mathbf{S 1}$ is the average of 5 pyrrolediones $^{9}$ that are found in the CSD. ${ }^{8}$ The trends in the bond distances and angles are all very similar to those found in structure $\mathbf{3}$, as discussed in the text. 
Specifically, the N1-C2 and C2-C3 bonds are long (1.379 $\AA$ and $1.542 \AA$, respectively). The $\mathrm{C} 2=\mathrm{O}$ carbonyl is shorter than the $\mathrm{C} 3=\mathrm{O}(1.206 \AA$ vs $1.217 \AA)$. The $\mathrm{C} 4-\mathrm{C} 3=\mathrm{O}$ angle is open $\left(131.8^{\circ}\right)$ corresponding to the formation of a ketene at this position and the $\mathrm{N} 1-\mathrm{C} 2=\mathrm{O}$ angle is smaller $\left(126.8^{\circ}\right)$ than the $\mathrm{C} 3-\mathrm{C} 2=\mathrm{O}$ angle $\left(127.9^{\circ}\right)$, which is consistent with the calculated trajectory for loss of carbon monoxide. Structures $\mathbf{S 3}$ - S6 are comparison structures that show that only with all of the components in a pyrroledione do the structures show distortions toward decarbonylation.

There are just two compounds that correspond to structure $\mathbf{S 2}{ }^{10}$ in the CSD, compounds that have the amide, bonded to an $\mathrm{sp}^{2}$ carbon (C3) with an oxygen attached. However, in these compounds, $\mathrm{C} 5$ is $\mathrm{sp}^{3}$ hybridized, and lacking conjugation, they cannot decarbonylate. These are related to compounds $\mathbf{7}$ and $\mathbf{8}$ in the text. Comparing $\mathbf{S 2}$ to $\mathbf{S 1}$, the $\mathrm{C} 2=\mathrm{O}$ bond is longer $(1.220 \AA$ vs 1.206 $\AA$ ), the N1-C2 bond is shorter (1.359 $\AA$ vs $1.379 \AA$ ) and the $\mathrm{C} 2-\mathrm{C} 3$ bond is much shorter (1.467 Å vs $1.542 \AA)$.

Structure S3 represents the average of 6 diones, ${ }^{11}$ but lacking conjugation at both $\mathrm{C} 4$ and $\mathrm{C} 5$, they again cannot decarbonylate. It is related to compound $\mathbf{6}$ in the text. The N1-C2 bond is shorter, and the $\mathrm{C} 2=\mathrm{O}$ bond is longer than in $\mathbf{S 1}$, consistent with more amide resonance. The $\mathrm{C} 2$ $\mathrm{C} 3$ bond in $\mathbf{S 3}$ is long (1.527 $\mathrm{A}$ ), but not as long as in $\mathbf{S 1}$. The C3=O carbonyl is shorter than the $\mathrm{C} 2=\mathrm{O}$ carbonyl, in contrast to $\mathbf{S 3}$ and $\mathbf{3}$. These are all consistent with distortion towards decarbonylation in $\mathbf{S 3}, \mathbf{3}$, and $\mathbf{4}$.

Structure $\mathbf{S} \mathbf{4}$ is the average of 3 compounds. ${ }^{12}$ They have the same hybridization and conjugation around the ring as $\mathbf{S 1}$ and $\mathbf{3}$, but lack the carbonyl at $\mathrm{C} 3$ and so cannot decarbonylate via a pseudopericyclic pathway. (They can decarbonylate via a non-planar, pericyclic transition state. ${ }^{13}$ The bond distances in $\mathbf{S 4}$ show little, if any, distortion toward decarbonylation. The $\mathrm{C} 2=\mathrm{O}$ bond is longer (1.224 $\AA$ ) and the $\mathrm{C} 2-\mathrm{C} 3$ bond is shorter (1.491 $\AA$ ) as compared to $\mathbf{S 1}$ and $\mathbf{3}$. The angles in $\mathbf{S 4}$ are less definitive. The $\mathrm{N} 1-\mathrm{C} 2=\mathrm{O}$ angle is small $\left(124.7^{\circ}\right)$ and the $\mathrm{C} 3-\mathrm{C} 2=\mathrm{O}$ angle is large $\left(129.6^{\circ}\right)$, a more pronounced distortion than in S1. However, the exocyclic alkenes at C3 are tetrasubstituted in all three structures; it seems reasonable to argue that steric crowding pushes the $\mathrm{C} 2=\mathrm{O}$ carbonyl away from $\mathrm{C} 3$. 
Structure S5 represents only a single structure, ${ }^{14}$ the unsubsituted cyclopentenetrione shown. The single bond between the carbonyls is long (1.521 $\AA$ ), but despite the repulsion by two flanking carbonyls, this is not as long as in S1 (1.542 $\AA$ ). Note as well, that the amide in S1 should stabilize the $\mathrm{C} 2=\mathrm{O}$ carbonyl and reduce the repulsion between the carbonyls, yet $\mathbf{S 1}$ has the longer single bond. All of the carbonyls in S5 are short (1.209 $\AA$ and $1.199 \AA$ ). The outside angle of $129.4^{\circ}$ is larger than the inside angle of $124.9^{\circ}$, but the difference is not as pronounced as in S1.

Structure S6 represents the average of 6 structures, ${ }^{15}$ in which the $\mathrm{C} 2=\mathrm{O}$ is replaced by an alkene; clearly loss of a vinylidine would be energetically unfavorable. (Cheletropic loss of vinylidenes is observed in some bicyclo[2,2,1]heptadiene systems. $\left.{ }^{16}\right)$ In $\mathbf{S 6}$, the C3=O bond is long (1.238 $\AA$ ) and the C5-N1 bond is short, indicating vinylogous amide resonance. On the other hand, the N1$\mathrm{C} 2=\mathrm{C}_{\text {exo }}$ angle $\left(128.8^{\circ}\right)$ is more open than the $\mathrm{C} 3-\mathrm{C} 2=\mathrm{C}_{\text {exo }}$ angle $\left(124.7^{\circ}\right)$, opposite to the trend in S1, 3, and 4 .

Structure S7 represents the average of 4 structures, ${ }^{17}$ which are mono-vinylogous imides. These structures were selected to not have complications from conjugation, strain or hydrogen bonding and none of the bonds are contained in aromatic rings. The distances are as would be expected if the conjugation in the vinylogous amide moiety is weaker than in the amide moiety. Specifically, the $\mathrm{C} 1=\mathrm{O}$ carbonyl is shorter than the $\mathrm{C} 5=\mathrm{O}(1.221 \AA$ vs $1.225 \AA)$, and the $\mathrm{C} 3$-N5 distance is longer than the N4-C5 distance (1.440 ̊ vs $1.369 \AA$ ). This confirms that the deviations from this trend in $\mathbf{S 1}, \mathbf{S 2}$, and $\mathbf{3}$ and $\mathbf{4}$ (specifically that the $\mathrm{C} 2=\mathrm{O}$ carbonyl is shorter than the $\mathrm{C} 3=\mathrm{O}$ carbonyl) are due to more than simple amide resonance. 

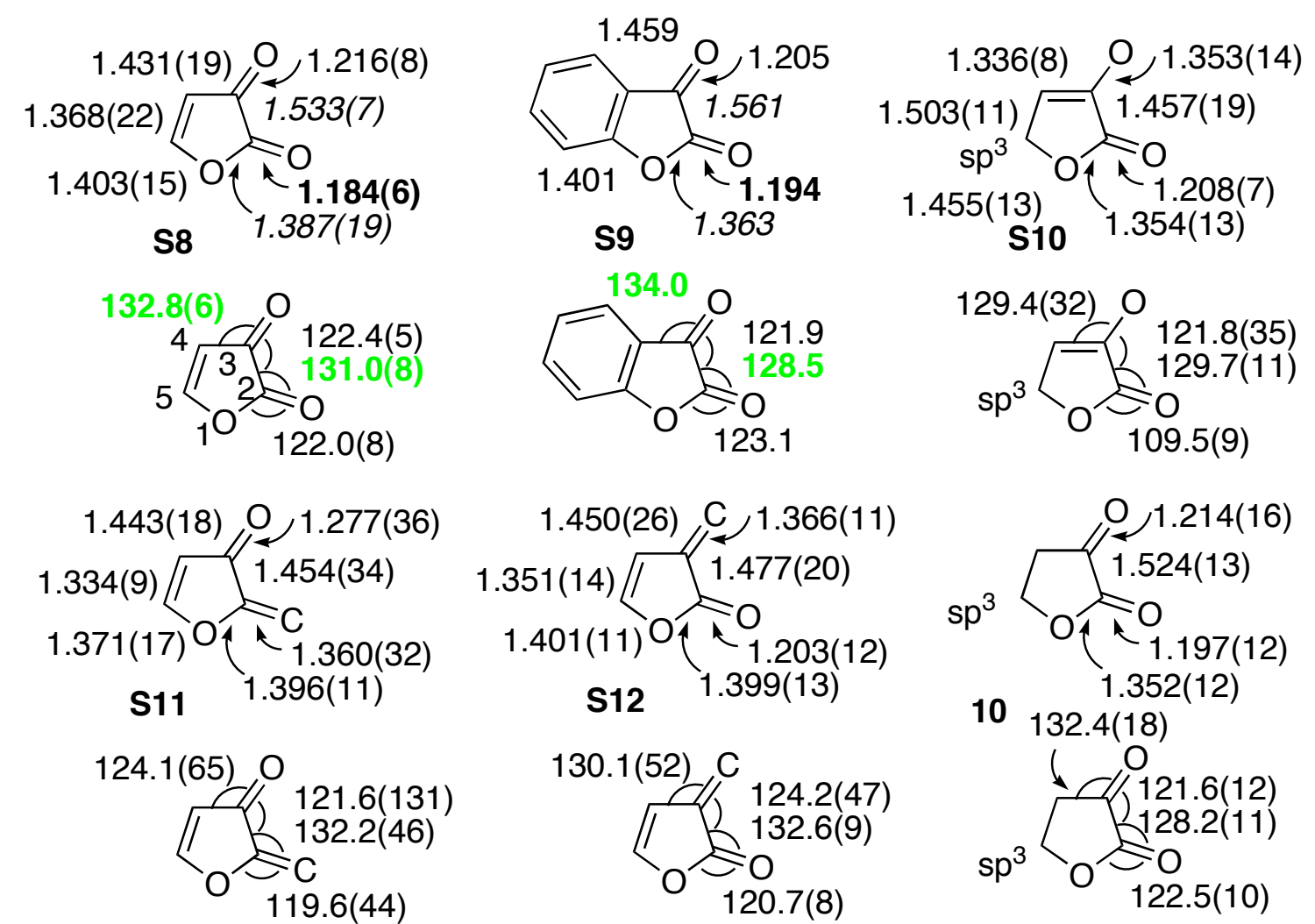

Figure S2. Average distances and angles of structures related to 9 and 10. See Figure S2 for key.

Structure S8 is the average of 5 structures. ${ }^{18}$ Only one of them has an R factor $<5 \%$, hence the rather large standard deviations in the distances and angles. The trends in the bond distances and angles are again consistent with ground-state distortions towards a planar, pseudopericyclic transition state for decarbonylation. In particular, the $\mathrm{C} 2=\mathrm{O}$ bond distance is short (1.184 $\mathrm{A})$ and the O1-C2 and C2-C3 distances are long (1.387 $\AA$ and $1.533 \AA$, respectively. These are more extreme than in any of the model systems S10 - S12 or 10. The bond angles similarly show distortions towards loss of $\mathrm{CO}$. The $\mathrm{C} 3-\mathrm{C} 2=\mathrm{O}$ angle of $131.0^{\circ}$ is much more open than the $\mathrm{O} 1-$ $\mathrm{C} 2=\mathrm{O}$ angle of $122.0^{\circ}$. However, similar trends are also seen in $\mathbf{S 1 0}-\mathbf{S 1 2}$ and in $\mathbf{1 0}$. Thus, this angle distortion is consistent, but not diagnostic. The $\mathrm{C} 4-\mathrm{C} 3=\mathrm{O}$ angle in $\mathbf{S 8}$ is also more open $\left(132.8^{\circ}\right)$ than the $\mathrm{C} 2-\mathrm{C} 3=\mathrm{O}$ angle $\left(122.4^{\circ}\right)$ and a similar trend is seen in $\mathbf{S 9}\left(134.8^{\circ}\right.$ and $\left.122.9^{\circ}\right)$. However, the angles in $\mathbf{1 0}$ are similarly distorted $\left(132.4^{\circ}\right.$ and $\left.121.6^{\circ}\right)$. Without the carbonyl at C2, these angles at C3 in S11 are much closer to each other $\left(124.1^{\circ}\right.$ and $\left.121.6^{\circ}\right)$. Overall, the distortions in $\mathbf{S 9}$ are consistent with the proposed distortion, particularly those of the bond distances. 
Structure S9 represents a single low temperature structure with an R factor of 5.42. ${ }^{19}$ As discussed above, the geometry reflects distortions towards the planar, pseudopericyclic transition state.

Structure S10 represents 18 structures. ${ }^{20}$ The substructure search yielded a number of salts of ascorbic acid derivatives; C5 was required to be sp3 hybridized. These show more of a lactone resonance structure, with a shorter O1-C2 distance (1.354 $\AA$ ) as compared to $\mathbf{S 8}(1.387 \AA)$ and a longer C2=O carbonyl distance (1.208 ̊v vs $1.184 \AA)$.

Structure S11 represents the average of 5 structures $^{21}$ that have the same hybridization around the ring, but have an exocyclic $\mathrm{C}=\mathrm{C}$ bond at $\mathrm{C} 2$ and thus will not readily lose a vinylidine. ${ }^{16}$ Most notably, the C2-C3 distance is nearly $0.1 \AA$ shorter than $\mathbf{S 8}(1.454 \AA$ vs $1.533 \AA$ ). The C4-C3=O angle is also quite small, compared to $\mathbf{S 7}\left(124.1^{\circ}\right.$ vs $\left.132.8^{\circ}\right)$.

Structure S12 represents the average of 5 structures $^{22}$ that have the same hybridization around the ring, but have an exocyclic $\mathrm{C}=\mathrm{C}$ bond at $\mathrm{C} 3$. Decarbonylation is possible, but not through a planar transition state. The carbonyl (C2=O, $1.203 \AA$ ) is longer than in $\mathbf{S 8}, \mathbf{S 9}$, or 10, reflecting more ester resonance. The C2-C3 bond is shorter (1.477 $\AA$ ), not prefiguring decarbonylation.

Structure 10 represents the average of 8 structures $^{23}$ that have an $\mathrm{sp}^{3}$ hybridized carbon at C5. Most are $\mathrm{sp}^{2}$ hybridized at C4. The C2-C3 bond (1.524 $\AA$ ), while longer than in S10 - S12, is shorter than in 9, S8 or S9 (1.534 $\AA$, $1.533 \AA$, or $1.561 \AA)$. Similarly, the O1-C2 bond is much shorter in $\mathbf{1 0}(1.352 \AA)$ than in 9, S8 or S9 (1.380 $\mathrm{A}, 1.387 \AA$ or $1.363 \AA$ ). The trends in the O1$\mathrm{C} 2=\mathrm{O}, \mathrm{O}=\mathrm{C} 2-\mathrm{C} 3, \mathrm{C} 2-\mathrm{C} 3=\mathrm{O}$ and $\mathrm{O}=\mathrm{C} 3-\mathrm{C} 4$ angles in $\mathbf{1 0}$ are similar to those in $\mathbf{9 ,} \mathbf{S 8}$ and $\mathbf{S 9}$. 


\section{Selected geometric parameters of 1 and 2 at the MP2/6-31G* level.}
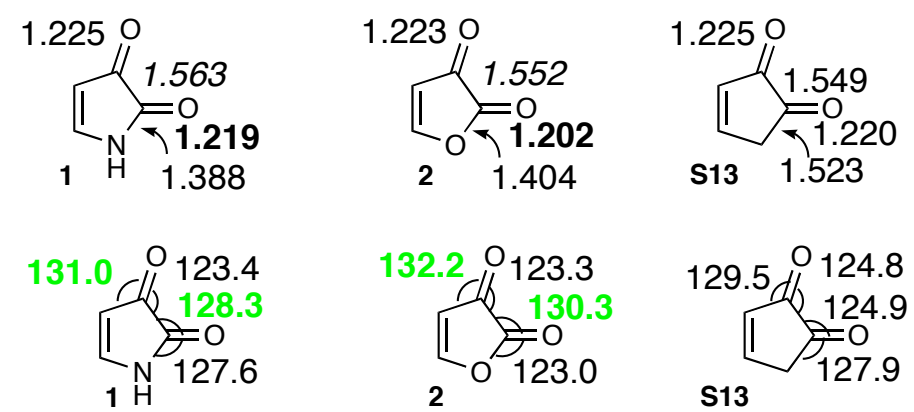

Figure S3. Selected bond lengths $(\AA)$ and angles (degrees) calculated at the MP2/6-31G* level of theory. Compound $\mathbf{1}$ is $\mathbf{7}$ from reference 13, compound $\mathbf{2}$ is $\mathbf{5}$ from reference 13 and $\mathbf{S 1 3}$ is $\mathbf{1 3}$ from reference 13. See Figure S1 for key.

Pyrolledione (1) and furandione (2) can decarbonylate via a planar, pseudopericyclic transition state, while 3-cyclopenten-1,2-dione (S13) requires a non-planar transition state for decarbonylation. The structure correlation principle predicts that $\mathbf{1}$ and $\mathbf{2}$ should show lengthening of the $\mathrm{C} 2-\mathrm{C} 3$ bonds and shortening of the $\mathrm{C}=\mathrm{O}$ bonds as compared to S13. Similarly, for 1 and 2, the $\mathrm{C} 4-\mathrm{C} 3=\mathrm{O}$ and $\mathrm{C} 3-\mathrm{C} 2=\mathrm{O}$ angles should be more open than the $\mathrm{C} 2-\mathrm{C} 3=\mathrm{O}$ and $\mathrm{O} 1$ $\mathrm{C} 2=\mathrm{O}$ angles, but this trend is not predicted for S13. The calculations clearly show these qualitative trends, in agreement with the structure correlation principle. These computational results also are consistent with a planar, pseudopericyclic transition state for decarbonylation of $\mathbf{1}$ and 2. 


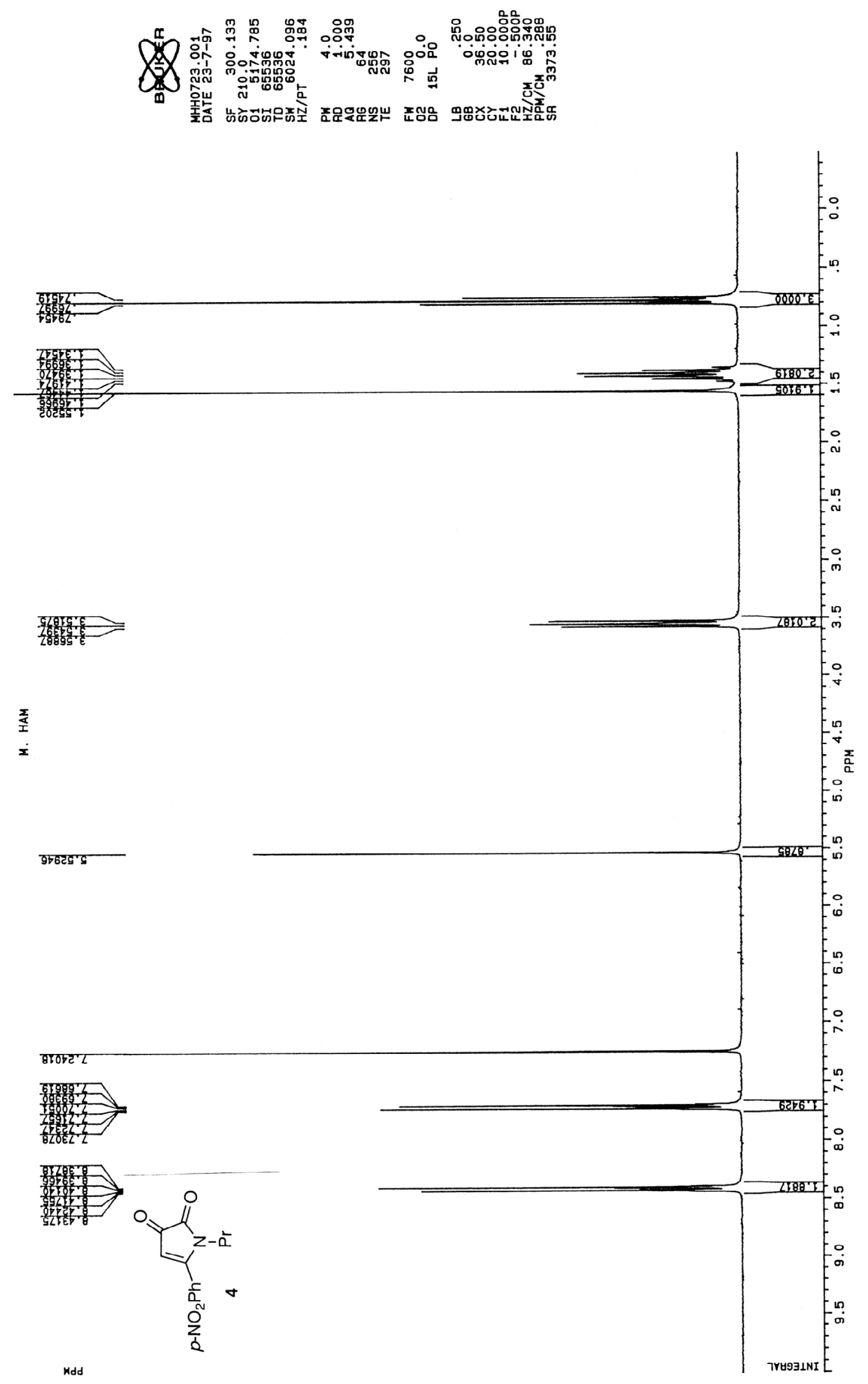




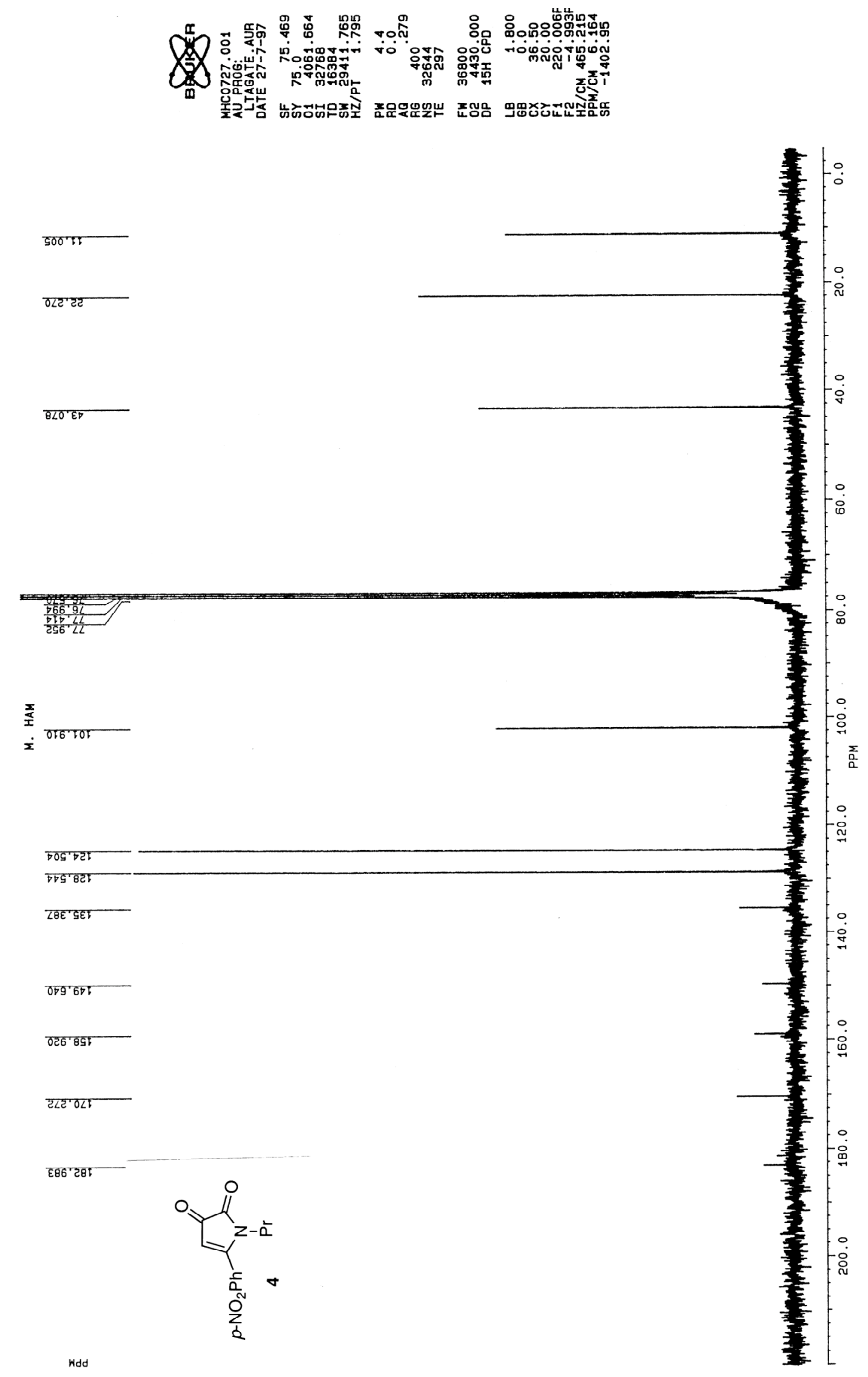




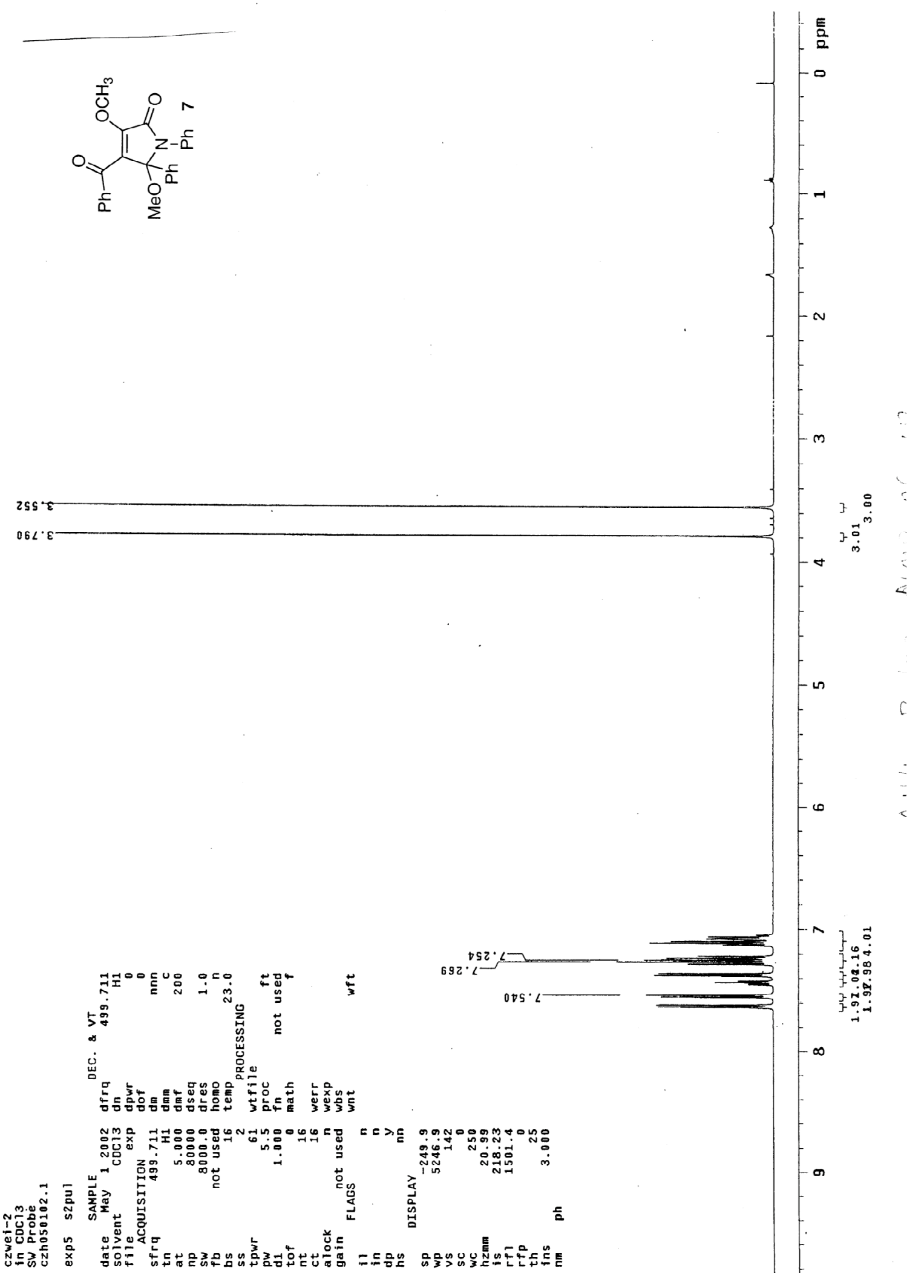




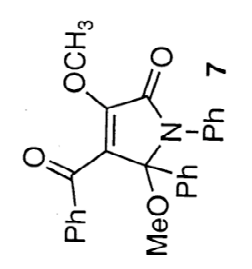

StD.0S

E)०.6s

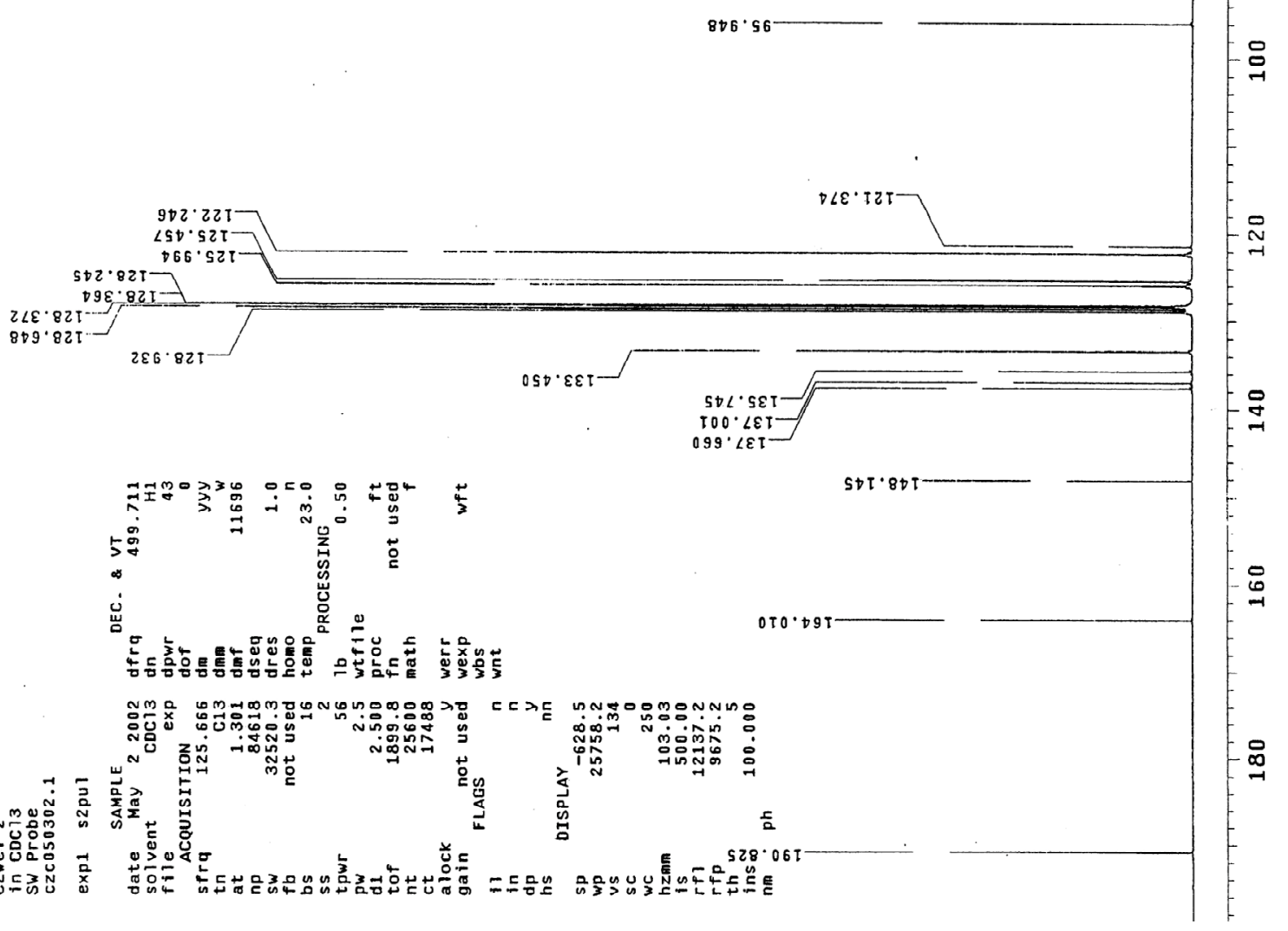



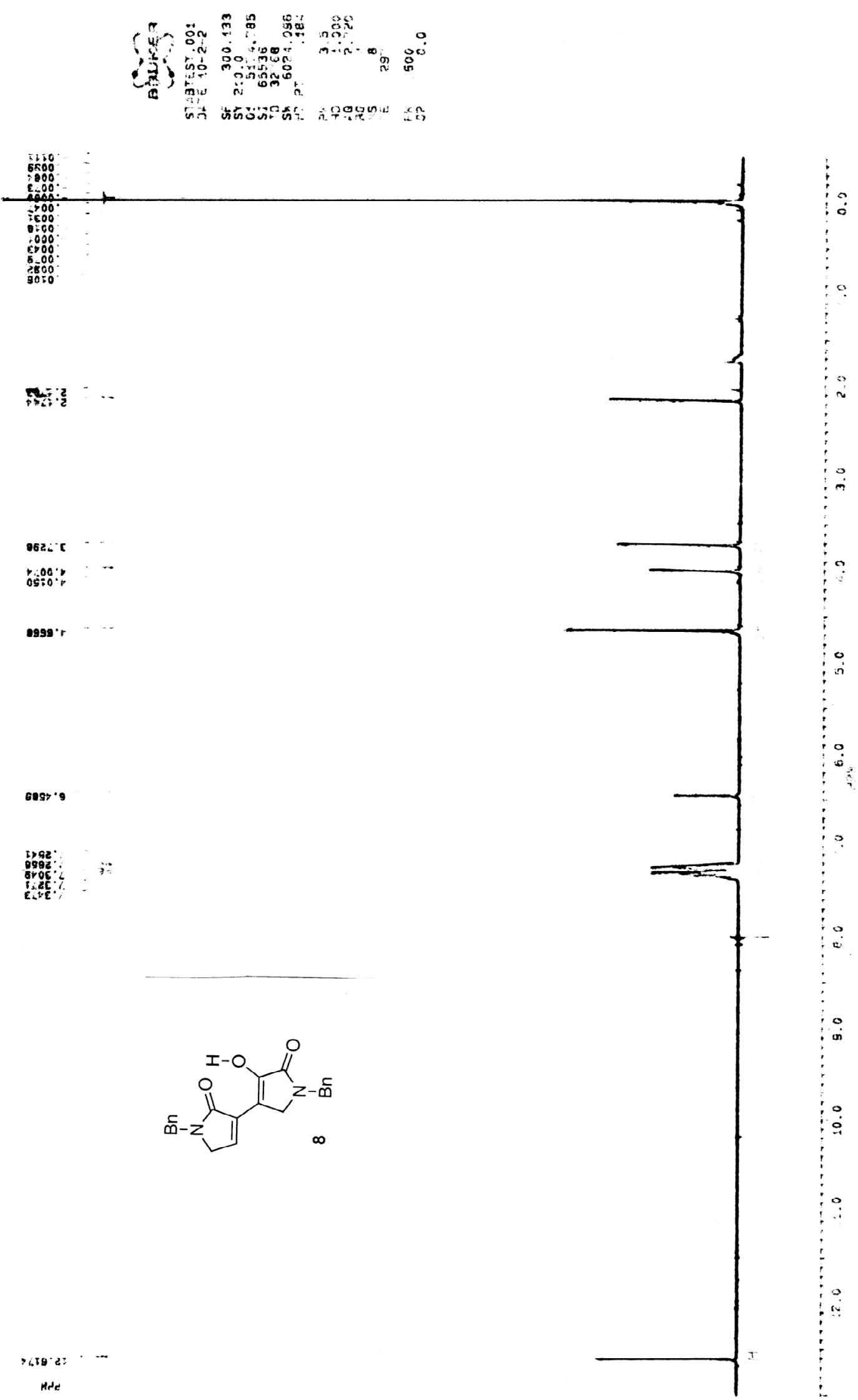


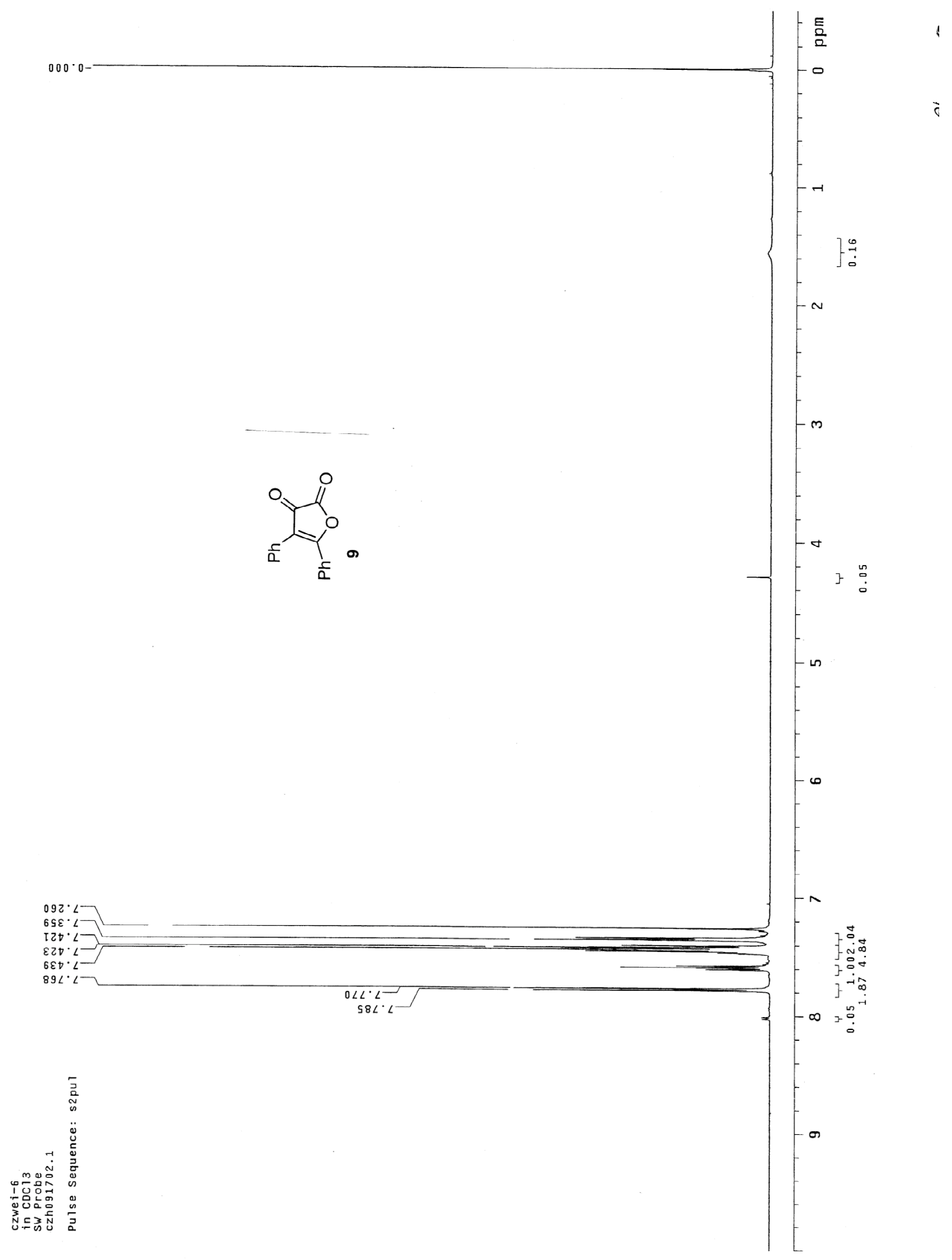




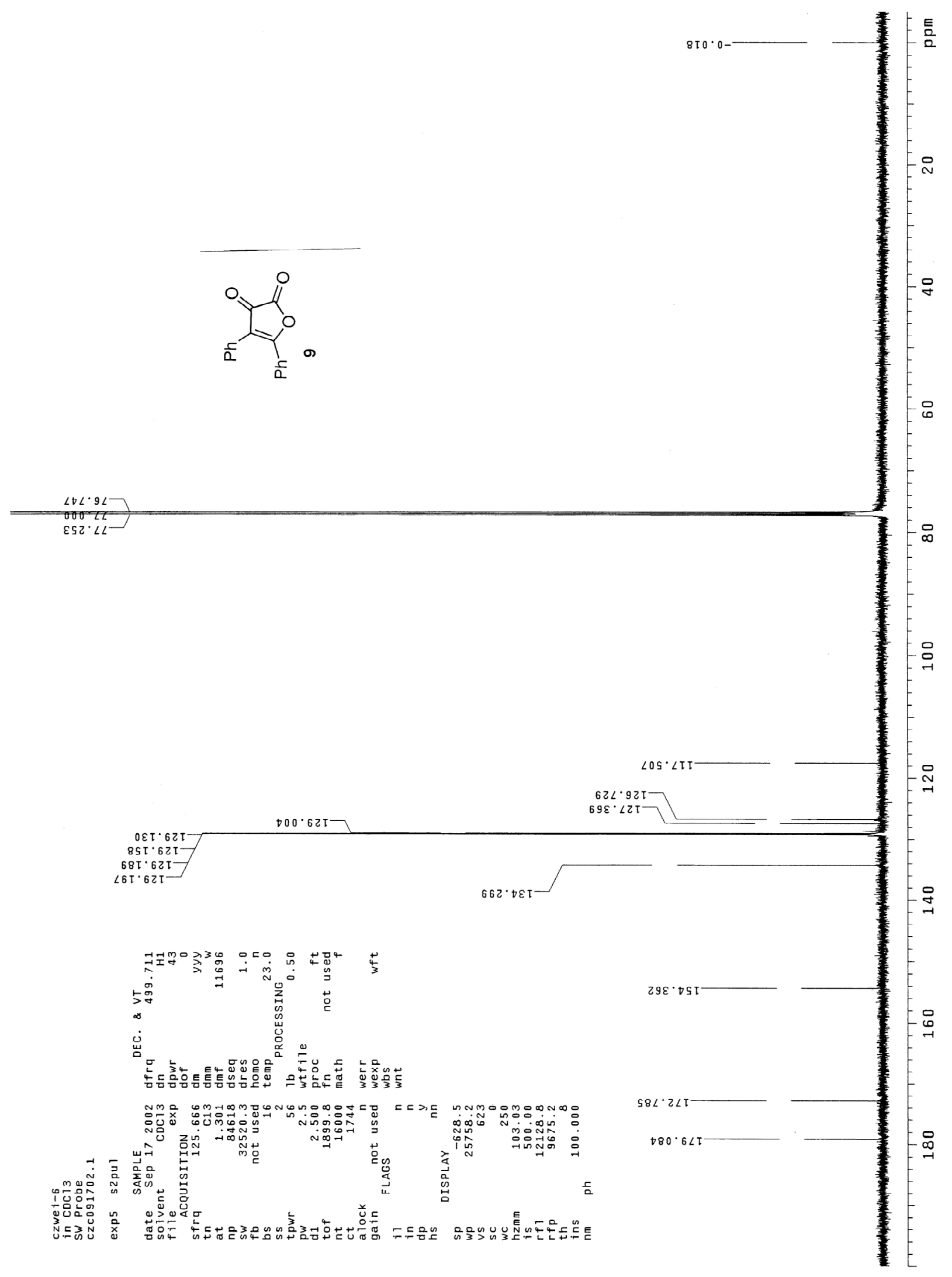




\section{STRUCTURE DETERMINATION SUMMARY}

\section{Crystal Data}

$\begin{array}{ll}\text { Empirical Formula } & \mathrm{C}_{13} \mathrm{H}_{12} \mathrm{~N}_{2} \mathrm{O}_{4} \\ \text { Color; Habit } & \text { red-orange obelisk } \\ \text { Crystal Size (mm) } & 0.40 \times 0.40 \times 1.00 \\ \text { Crystal System } & \text { Monoclinic } \\ \text { Space Group } & \mathrm{C} 2 / \mathrm{c} \\ \text { Unit Cell Dimensions } & \underline{\mathrm{a}}=12.326(2) \AA \\ & \underline{\mathrm{b}}=11.255(2) \AA \\ & \underline{\mathrm{c}}=18.552(4) \AA \\ \text { Volume } & \beta=109.07(3)^{\circ} \\ \text { Z } & 2432.5(8) \AA^{3} \\ \text { Formula Weight } & 8 \\ \text { Density(calc.) } & 260.2 \\ \text { Absorption Coefficient } & 1.421 \mathrm{Mg}^{3} \mathrm{~m}^{3} \\ \text { F(000) } & 0.107 \mathrm{~mm}^{-1} \\ & 1088\end{array}$

$F(000)$

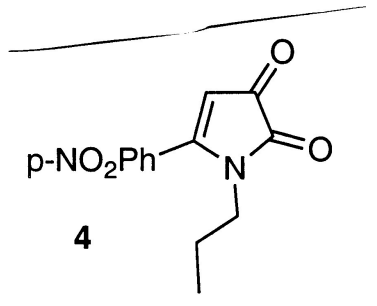


Data Collection

\begin{tabular}{|c|c|}
\hline Diffractometer Used & Siemens P4 \\
\hline Radiation & $\operatorname{MoK} \alpha(\lambda=0.71073 \AA)$ \\
\hline Temperature (K) & 173 \\
\hline Monochromator & Highly oriented graphite crystal \\
\hline $2 \theta$ Range & 3.5 to $50.0^{\circ}$ \\
\hline Scan Type & $2 \theta-\theta$ \\
\hline Scan Speed & Variable; 4.00 to $60.00^{\circ} / \mathrm{min}$. in $\omega$ \\
\hline Scan Range $(\omega)$ & $0.96^{\circ}$ plus K $\alpha$-separation \\
\hline Background Measurement & $\begin{array}{l}\text { Stationary crystal and stationary } \\
\text { counter at beginning and end of } \\
\text { scan, each for } 25.0 \% \text { of total } \\
\text { scan time }\end{array}$ \\
\hline Standard Reflections & 3 measured every 97 reflections \\
\hline Index Ranges & $\begin{array}{l}-1 \leq h \leq 14,-1 \leq k \leq 13 \\
-22 \leq \ell \leq 21\end{array}$ \\
\hline Reflections Collected & 2742 \\
\hline Independent Reflections & $2140\left(R_{\text {int }}-3.13 \%\right)$ \\
\hline Observed Reflections & $1727(F>4.0 \sigma(F))$ \\
\hline Absorption Correction & $\mathrm{N} / \mathrm{A}$ \\
\hline
\end{tabular}


Solution and Refinement

$\begin{array}{ll}\text { System Used } & \text { Siemens SHELXTL IRIS } \\ \text { Solution } & \text { Direct Methods } \\ \text { Refinement Method } & \text { Full-Matrix Least-Squares } \\ \text { Quantity Minimized } & \sum_{\mathrm{w}\left(\mathrm{F}_{\mathrm{o}}-\mathrm{F}_{\mathrm{c}}\right)^{2}} \\ \text { Absolute Structure } & \mathrm{N} / \mathrm{A} \\ \text { Extinction Correction } & \mathrm{N} / \mathrm{A} \\ \text { Hydrogen Atoms } & \mathrm{Riding} \text { model, fixed isotropic U } \\ \text { Weighting Scheme } & \mathrm{w}-1=\sigma^{2}(\mathrm{~F})+0.0359 \mathrm{~F}^{2} \\ \text { Number of Parameters Refined } & 172 \\ \text { Final R Indices (obs. data) } & \mathrm{R}=5.37 \%, \text { wR }=8.52 \% \\ \text { R Indices (all data) } & \mathrm{R}=7.20 \%, \text { wR }=12.27 \% \\ \text { Goodness-of-Fit } & 0.45 \\ \text { Largest and Mean } \Delta / \sigma & 0.036,0.010 \\ \text { Data-to-Parameter Ratio } & 10.0: 1 \\ \text { Largest Difference Peak } & 0.34 \mathrm{eA}^{-3} \\ \text { Largest Difference Hole } & -0.46 \mathrm{e}^{-3}\end{array}$


Table 1. Atomic coordinates $\left(\times 10^{4}\right)$ and equivalent isotropic

\begin{tabular}{lcrrr}
\multicolumn{5}{c}{ displacement coefficients $\left(\AA^{2} \times 10^{3}\right)$} \\
& $\mathrm{x}$ & $\mathrm{y}$ & $\mathrm{z}$ & $\mathrm{U}(\mathrm{eq})$ \\
$\mathrm{O}(1)$ & $6725(2)$ & $1336(2)$ & $4222(1)$ & $36(1)$ \\
$\mathrm{O}(2)$ & $8466(2)$ & $1957(2)$ & $4437(1)$ & $45(1)$ \\
$\mathrm{O}(3)$ & $5456(1)$ & $1341(1)$ & $-1112(1)$ & $28(1)$ \\
$\mathrm{O}(4)$ & $7943(1)$ & $949(1)$ & $-660(1)$ & $27(1)$ \\
$\mathrm{N}(1)$ & $7534(2)$ & $1621(2)$ & $4008(1)$ & $27(1)$ \\
$\mathrm{N}(2)$ & $7835(2)$ & $1181(2)$ & $554(1)$ & $21(1)$ \\
$\mathrm{C}(1)$ & $7377(2)$ & $1527(2)$ & $3190(1)$ & $22(1)$ \\
$\mathrm{C}(2)$ & $6555(2)$ & $755(2)$ & $2749(1)$ & $25(1)$ \\
$\mathrm{C}(3)$ & $6417(2)$ & $678(2)$ & $1980(1)$ & $24(1)$ \\
$\mathrm{C}(4)$ & $7093(2)$ & $1365(2)$ & $1660(1)$ & $20(1)$ \\
$\mathrm{C}(5)$ & $7913(2)$ & $2139(2)$ & $2125(1)$ & $23(1)$ \\
$\mathrm{C}(6)$ & $8070(2)$ & $2218(2)$ & $2897(1)$ & $25(1)$ \\
$\mathrm{C}(7)$ & $6895(2)$ & $1276(2)$ & $836(1)$ & $20(1)$ \\
$\mathrm{C}(8)$ & $5870(2)$ & $1335(2)$ & $268(1)$ & $24(1)$ \\
$\mathrm{C}(9)$ & $6082(2)$ & $1279(2)$ & $-450(1)$ & $23(1)$ \\
$\mathrm{C}(10)$ & $7403(2)$ & $1118(2)$ & $-230(1)$ & $21(1)$ \\
$\mathrm{C}(11)$ & $8976(2)$ & $699(2)$ & $982(1)$ & $24(1)$ \\
$\mathrm{C}(12)$ & $8917(2)$ & $-598(2)$ & $1210(1)$ & $28(1)$ \\
$\mathrm{C}(13)$ & $10110(3)$ & $-1107(3)$ & $1574(2)$ & $45(1)$
\end{tabular}

* Equivalent isotropic $U$ defined as one third of the trace of the orthogonalized $U_{i j}$ tensor

Table 2. Bond lengths ( $\AA$ )

$\begin{array}{lll}O(1)-N(1) & 1.229(3) \\ O(3)-C(9) & 1.221 & (2) \\ N(1)-C(1) & 1.470(3) \\ N(2)-C(10) & 1.378(3) \\ C(1)-C(2) & 1.381(3) \\ C(2)-C(3) & 1.383(3) \\ C(4)-C(5) & 1.398(3) \\ C(5)-C(6) & 1.384(3) \\ C(8)-C(9) & 1.440(4) \\ C(11)-C(12) & 1.527(3)\end{array}$

$\begin{array}{lll}O(2)-N(1) & 1.225 & (3) \\ O(4)-C(10) & 1.210 & (3) \\ N(2)-C(7) & 1.421 & (3) \\ N(2)-C(11) & 1.474 & (3) \\ C(1)-C(6) & 1.390(4) \\ C(3)-C(4) & 1.402(3) \\ C(4)-C(7) & 1.472(3) \\ C(7)-C(8) & 1.357(3) \\ C(9)-C(10) & 1.554(3) \\ C(12)-C(13) & 1.516 & (4)\end{array}$


Table 3. Bond angles $\left({ }^{\circ}\right)$

$\begin{array}{llll}O(1)-N(1)-O(2) & 123.9(2) & O(1)-N(1)-C(1) & 117.9(2) \\ O(2)-N(1)-C(1) & 118.2(2) & C(7)-N(2)-C(10) & 108.2(2) \\ C(7)-N(2)-C(11) & 125.3(2) & C(10)-N(2)-C(11) & 121.4(2) \\ N(1)-C(1)-C(2) & 118.7(2) & \mathrm{N}(1)-C(1)-C(6) & 118.2(2) \\ C(2)-C(1)-C(6) & 123.1(2) & C(1)-C(2)-C(3) & 118.0(2) \\ C(2)-C(3)-C(4) & 120.8(2) & C(3)-C(4)-C(5) & 119.5(2) \\ C(3)-C(4)-C(7) & 118.8(2) & C(5)-C(4)-C(7) & 121.6(2) \\ C(4)-C(5)-C(6) & 120.5(2) & C(1)-C(6)-C(5) & 118.1(2) \\ N(2)-C(7)-C(4) & 120.6(2) & N(2)-C(7)-C(8) & 112.5(2) \\ C(4)-C(7)-C(8) & 126.8(2) & C(7)-C(8)-C(9) & 108.1(2) \\ O(3)-C(9)-C(8) & 133.0(2) & O(3)-C(9)-C(10) & 122.3(2) \\ C(8)-C(9)-C(10) & 104.7(2) & O(4)-C(10)-N(2) & 126.8(2) \\ O(4)-C(10)-C(9) & 126.9(2) & N(2)-C(10)-C(9) & 106.3(2) \\ N(2)-C(11)-C(12) & 112.2(2) & C(11)-C(12)-C(13) & 111.0(2)\end{array}$

Table 4. Anisotropic displacement coefficients $\left(\AA^{2} \times 10^{3}\right)$

\begin{tabular}{lrrrrrr} 
& $\mathrm{U}_{11}$ & $\mathrm{U}_{22}$ & $\mathrm{U}_{33}$ & $\mathrm{U}_{12}$ & $\mathrm{U}_{13}$ & \multicolumn{1}{c}{$\mathrm{U}_{23}$} \\
$\mathrm{O}(1)$ & $47(1)$ & $34(1)$ & $36(1)$ & $4(1)$ & $26(1)$ & $1(1)$ \\
$\mathrm{O}(2)$ & $50(1)$ & $58(1)$ & $24(1)$ & $-15(1)$ & $8(1)$ & $-8(1)$ \\
$\mathrm{O}(3)$ & $31(1)$ & $26(1)$ & $19(1)$ & $-3(1)$ & $0(1)$ & $0(1)$ \\
$\mathrm{O}(4)$ & $33(1)$ & $26(1)$ & $25(1)$ & $-4(1)$ & $14(1)$ & $-3(1)$ \\
$\mathrm{N}(1)$ & $35(1)$ & $24(1)$ & $25(1)$ & $4(1)$ & $14(1)$ & $2(1)$ \\
$\mathrm{N}(2)$ & $21(1)$ & $22(1)$ & $19(1)$ & $1(1)$ & $7(1)$ & $0(1)$ \\
$\mathrm{C}(1)$ & $28(1)$ & $20(1)$ & $20(1)$ & $3(1)$ & $9(1)$ & $2(1)$ \\
$\mathrm{C}(2)$ & $25(1)$ & $26(1)$ & $25(1)$ & $-2(1)$ & $10(1)$ & $1(1)$ \\
$\mathrm{C}(3)$ & $24(1)$ & $23(1)$ & $25(1)$ & $-2(1)$ & $8(1)$ & $-1(1)$ \\
$\mathrm{C}(4)$ & $21(1)$ & $19(1)$ & $20(1)$ & $2(1)$ & $6(1)$ & $1(1)$ \\
$\mathrm{C}(5)$ & $26(1)$ & $22(1)$ & $21(1)$ & $-4(1)$ & $6(1)$ & $0(1)$ \\
$\mathrm{C}(6)$ & $30(1)$ & $19(1)$ & $24(1)$ & $-5(1)$ & $7(1)$ & $-3(1)$ \\
$\mathrm{C}(7)$ & $22(1)$ & $16(1)$ & $23(1)$ & $-3(1)$ & $8(1)$ & $-2(1)$ \\
$\mathrm{C}(8)$ & $22(1)$ & $26(1)$ & $23(1)$ & $-3(1)$ & $5(1)$ & $-2(1)$ \\
$\mathrm{C}(9)$ & $26(1)$ & $18(1)$ & $21(1)$ & $-3(1)$ & $4(1)$ & $0(1)$ \\
$\mathrm{C}(10)$ & $27(1)$ & $13(1)$ & $22(1)$ & $-5(1)$ & $7(1)$ & $0(1)$ \\
$\mathrm{C}(11)$ & $21(1)$ & $25(1)$ & $23(1)$ & $1(1)$ & $5(1)$ & $2(1)$ \\
$\mathrm{C}(12)$ & $32(1)$ & $29(1)$ & $24(1)$ & $3(1)$ & $9(1)$ & $3(1)$ \\
$\mathrm{C}(13)$ & $47(2)$ & $52(2)$ & $46(2)$ & $25(1)$ & $28(1)$ & $21(1)$
\end{tabular}

The anisotropic displacement factor exponent takes the form:

$-2 \pi^{2}\left(h^{2} a *^{2} U_{11}+\ldots+2 h k a * b * U_{12}\right)$ 
Table 5. H-Atom coordinates $\left(\times 10^{4}\right)$ and isotropic displacement coefficients $\left(\AA^{2} \times 10^{3}\right)$

$\begin{array}{lrrrr} & \mathbf{x} & \boldsymbol{y} & \mathbf{z} & \mathrm{U} \\ \mathrm{H}(2) & 6133 & 217 & 3042 & 50 \\ \mathrm{H}(3) & 5859 & 112 & 1590 & 50 \\ \mathrm{H}(5) & 8419 & 2683 & 1933 & 50 \\ \mathrm{H}(6) & 8604 & 2799 & 3200 & 50 \\ \mathrm{H}(8) & 5106 & 1487 & 380 & 50 \\ \mathrm{H}(11 \mathrm{~A}) & 9344 & 1220 & 1459 & 50 \\ \mathrm{H}(11 \mathrm{~B}) & 9420 & 791 & 587 & 50 \\ \mathrm{H}(12 \mathrm{~A}) & 8442 & -1014 & 760 & 50 \\ \mathrm{H}(12 \mathrm{~B}) & 8494 & -614 & 1554 & 50 \\ \mathrm{H}(13 \mathrm{~A}) & 10117 & -1914 & 1805 & 50 \\ \mathrm{H}(13 \mathrm{~B}) & 10580 & -572 & 1998 & 50 \\ \mathrm{H}(13 \mathrm{C}) & 10375 & -1187 & 1234 & 50\end{array}$




\section{References:}

1. Roberts, E.; Turner, E. E. J. Chem. Soc. [London] 1927, 1832-1857.

2. Kollenz, G.; Igel, H.; Ziegler, E. Monatsh. Chem. 1972, 103, 450-459.

3. Kappe, C. O.; Terpetschnig, E.; Penn, G.; Kollenz, G.; Peters, K.; Peters, E.-M.; von Schnering, H. G. Liebigs Ann. 1995, 537-543.

4. (a) Palmer, M. H.; Blake, A. J.; Gould, R. O., Chem. Phys. 1987, 115, 219. (b) Palenik, G. J.; Koziol, A. E.; Katritzky, A. R.; Fan, W.-Q., J. Chem. Soc., Chem. Commun. 1990, 715716. (c) Rathna, A.; Chandrasekhar, J., J. Chem. Soc., Chem. Commun. 1991, 1661-1666. (d) Frolova, N. A.; Kravlsov, V. K.; Blyushkin, V. N.; Chumalov, Y. M.; Bel'kova, O. N.; Malinovski, T. I., Zh. Strukt. Khim. (Russ) 1999, 29, 155-3.

5. Baldwin, J. E.; Chan, M. F.; Gallacher, G.; Otsuka, M.; Monk, P.; Prout, K. Tetrahedron 1984, 40, 4513-4525.

6. House, H. O.; Czuba, L. J.; Gall, M.; Olmstead, H. D. J. Org. Chem. 1969, 34, 2324-2336.

7. Murai, V. S.; Hasegawa, K.; Sonoda, N. Angew. Chem. 1975, 87, 668-669.

8. CSD Version 5.20 (Oct. 2000) Allen, F. H.; Davies, J. E.; Galloy, J. J.; Johnson, O.; Kennard, O.; Macrae, C. F.; Mitchell, E. M.; Mitchell, G. F.; Smith, J. M.; Watson, D. G. J. Chem. Inf. Comput. Sci. 1991, 31, 187-204. In references below, the CSD identifier for the structure is provided, along with the literature reference.

9. S1, PIKYIR, Tsuda, Y.; Hosoi, S.; Katagiri, N.; Kaneko, C.; Sano, T., Chem. Pharm. Bull. 1993, 41, 2087. TOTCUA, Davies, G. M.; Hitchcock, P. B.; Loakes, D.; Young, D. W., Tetrahedron Lett. 1996, 37, 5601. TOKQUF, Grochowski, J.; Serda, P.; Dauter, Z.; Kolasa, A., Z. Kristallogr. 1996, 211, 622. NUQTUO, Aliev, Z. G.; Shurov, S. N.; Glushkov, V. A.; Karpova, L. N.; Andreichikov, Y. S.; Atovmyan, L. O., Izv. Akad. Nauk SSSR, Ser. Khim. 
(Russ). 1997, 1845. JURJEL, Zorn, C.; Goti, A.; Brandi, A.; Johnsen, K.; Noltemeyer, M.;

Kozhushkov, S. I.; de Meijere, A., J. Org. Chem. 1999, 64, 755.

10. S2, QOZYUZ, Khan, M. A.; Adams, H., Carbohydr. Res. 1999, 322, 279. XINHIL, Aliev, Z. G.; Krashykh, O. P.; Konyukhova, N. A.; Maslivets, A. N., Zh. Strukt. Khim. (Russ) 2001, $42,1008$.

11. S3, KAHDUS, Kollenz, G.; Penn, G.; Ott, W.; Peters, K.; Peters, E.-M.; von Schnering, H. G., Chem. Ber. 1984, 117, 1310. LAJNIT, LAJNUF, Sano, T.; Hirose, M.; Horiguchi, Y.; Kiochi, F.; Tsuda, Y., Chem. Pharm. Bull. 1993, 41, 64. PIKYOZ, Tsuda, Y.; Hosoi, S.; Katagiri, N.; Kaneko, C.; Sano, T., Chem. Pharm. Bull. 1993, 41, 2087. TESSAL, TESSEP, Horiguchi, Y.; Sano, T.; Kiuchi, F.; Tsuda, Y., Chem. Pharm. Bull. 1996, 44, 681.

12. S4, DIZNEF, Wamhoff, H.; Schupp, W.; Kirfel, A.; Will, G., J. Org. Chem. 1986, 51, 149. FAXPUP, Soriano-Garcia, M.; Serrano, J. S. X.; Jimenez, F. G., Acta Crystallogr., Sect. C:Cryst. Struct. Commun. 1986, 42, 1828. ZUHRUP, Iijima, K.; Irikawa, H., Acta Crystallogr., Sect. C:Cryst. Struct. Commun. 1996, 52, 1003.

13. Birney, D. M.; Ham, S.; Unruh, G. R., J. Am. Chem. Soc. 1997, 119, 4509-4517.

14. S5, CIMNUH, Imgartinger, H.; Nixdorf, M.; Dobler, W.; Gleiter, W., Acta Crystallogr., Sect. C:Cryst. Struct. Commun. 1984, 40, 1481.

15. S6, TXMPPD, Clark, H. C.; Milne, C. R. C.; Payne, N. C., J. Am. Chem. Soc. 1978, 100, 1164. TAGRUO, Kakehi, A.; Ito, S.; Fujii, T.; Sekurai, T.; Urushido, K.; Hatanaka, S.; Mabuchi, T.; Matsushita, S., Bull. Chem. Soc. Jpn. 1990, 63, 3571. JOXYEA, Hemming, K.; Redhouse, A. D.; Smalley, R. K.; Thompson, J. R., Tetrahedron Lett. 1992, 33, 2231. ZIZSIK, Aliev, Z. G.; Maslivets, A. N.; Simonchik, O. L.; Konyukhova, T. G.; Andreichikov, Y. S.; Atovmyan, L. O., Izv. Akad. Nauk SSSR, Ser. Khim. (Russ). 1995, 1556. ZIHHIH, Ma, L.; Dolphin, D., J. Chem. Soc., Chem. Commun. 1995, 2251. GISGAQ, Lin, Q.; Djaidi, D.; Bishop, R.; Craig, D. C.; Scudder, M. L., Aust. J. Chem. 1998, 51, 799. 
16. Hoffmann, R. W., Acc. Chem. Res. 1985, 18, (8), 248-253.

17. S7, DEHQEM, Suarez, M.; Ochoa, E.; Verdecia, Y.; Pita, B.; Moran, L.; Martin, N.; Quinteiro, M.; Seoane, C.; Soto, J. L.; Novoa, H.; Blanton, N.; Peters, O. M., Tetrahedron 1999, 55, 875. DEHQEM01, Tu, S.-J.; Shi, D.-Q.; Yao, C.-S.; Wang, S.-H.; Wang, X.-S.; Wang, Y.-C.; Dai, G.-Y., Jiegou Huaxue (Chin.)(Chinese J. Struct. Chem.) 2001, 20, 49. LERVEJ, LERVIN, Amin, M.; Wessig, P.; Henning, H.-G.; Reck, G.; Schultz, B., J. Prakt. Chem. -Chem.-Zeitung 1994, 336, 169.

18. S8, IDIJIO, R factor 4.48\%, Hokelek, T.; Sarinpar, E.; Yildrim, I.; Akkut, M.; Akcamur, Y., Acta Crystallogr., Sect. C:Cryst. Struct. Commun. 2000, 58, 30. SOLSAN, Saalfrank, R. W.; Lutz, T.; Horner, B.; Gundel, J.; Peters, K.; von Schnering, H. G., Chem. Ber. 1991, 124, 2289. TIZFAJ, Saalfrank, R. W.; Horner, B.; Reck, S.; Nachtrab, J.; Peters, E.-M.; Peters, K.; von Schnering, H. G., Z. Naturforsch. B Chem. Sci. 1996, 51, 1084. WEJMED, Bonnaud, B.; Hnach, M.; Aycard, J. P.; Lapassat, J., J. Crystallogr. Spectrosc. Res. 1993, 23, 993. YAWZOL, Bonnaud, B.; Hnach, M.; Aycard, J. P.; Lapassat, J., J. Crystallogr. Spectrosc. Res. 1993, 23, 563.

19. S9, MEYCUO Rozenberg, V.; Danilova, T.; Sergeeva, E.; Vorontsov, E.; Stanikova, Z.; Korlyukov, A.; Hopf, H., Eur. J. Chem. 2002, 468.

20. S10, BAGSAE, BAGSEI, CEBNIG, IASCOR10, KUXCEL, LASCAC10, MACHYF10, NETROT, NIBXEB, NOQDUS, QULDIK, REJDOZ, SERASC10, VADZUV, YIYZAH, Because of the large number of structures, these are not all referenced here.

21. S11, DIVWEK, Kollenz, G.; Biedermann, A.; Peters, K.; Peters, E.-M.; von Schnering, H. G., J. Chem. Res. 1985, 288, 2976. GEYZUF, GEYZUF01, Jeffrey, G. A.; Yeon, Y., Carbohydr. Res. 1988, 174, 1. LELWEE, Aliev, Z. G.; Atovmyan, L. O.; Koz'minykh, V. O.; Andreichikov, Y. S., Izv. Akad. Nauk SSSR, Ser. Khim.(Russ). 1992, 520.

22. S12, HOCVIE, Krapivin, G. D.; Kozhina, N. D.; Chemoursenko, L. A.; Zavodnik, V. E., Khim. Get. Soedin., SSSR(Russ) 1999, 24. MSFURY01, Begley, M. J.; Crombie, L.; G. L. 
Griffiths; Jones, R. C. F.; Rahmani, M., R. Chem. Soc., Chem. Commun. 1981, 823.

QENZIS, Al-Shihry, S. S., J. Chem. Res. 2000, 526. SIXPEU, Terpetschnig, E.; Penn, G.;

Kollenz, G.; Peters, K.; Peters, E.-M.; Schnering, H. G. v., Tetrahedron 1991, 47, 3045.

23. 10, COKZEH, COKZOR, Kollenz, G.; Ott, W.; Zeigler, E.; Peters, E.-M.; Peters, K.; von Schnering, H. G.; Formacek, V.; Quast, H., Liebigs Ann. 1984, 1137. FOYYEX, FOYYIB, Kollenz, G.; Penn, G.; Ott, W.; Peters, K.; Peters, E.-M.; von Schnering, H. G.; Formacek, V.; Quast, H., Heterocycles 1987, 625. NINJOJ, Sano, T.; Koseki, N.; Saitoh, T.; Horiguchi, Y.; Toda, J.; Kiuchi, F.; Tsuda, Y., Chem. Pharm. Bull. 1997, 45, 608. PEVZUL, Heilmayer, W.; Kappe, C. O.; Sterk, H.; Kollenz, G.; Peters, K.; Peters, E.-M.; von Schnering, H. G., Chem. Ber. 1993, 126, 2061. VORJIV, Zimmer, H.; Amer, A.; Ho, D.; Palmer-Sungail, R., J. Heterocycl. Chem 1991, 28, 1501. 